\title{
A Pilot Study to Evaluate the Role of Santarpan Manth in Protein Energy Malnutrition (PEM)
}

\author{
Research Article
}

\section{Astha Sharma $^{*}$, Shiv Shankar Shukla ${ }^{2}$}

1. PG Scholar, Department of Swasthavritta, National Institute of Ayurveda, Jaipur.

2. Assistant Professor, Government Ayurvedic College, Burhanpur, Madhya Pradesh.

\begin{abstract}
Background and objectives: - PEM is a type of malnutrition resulting from deficiency of proteins and calories in food over a long period of time. India ranked $2^{\text {nd }}$ after Bangladesh in world in malnutrition of children. Hence there is a sustained need of developing a nutritious food supplement which could provide better nutrients to eliminate or improve the malnutrition related problems, within the reach of majority even in rural area also. With objective to evaluate the role of Santarpan Manth in Protein Energy Malnutrition. Design: Open Randomized Prospective clinical study. Participants: - children of age group 2-5 yrs. Method: -30 patients were selected from OPD and IPD of Balroga, NIA, Jaipur. They were randomly divided in two groups. Santarpan Manth-1 in Group A and Santarpan Manth-II in Group B (Placebo Group ) administered for three months of duration with follow up at every fifteen days. Outcome measures:- Anthropometry parameters i.e. Weight, Height, MAC, Skin fold thickness and chest circumference : Laboratory parameters i.e. Hb, and TSP. Results: - significant improvement in anthropometric parameters in group A, and in laboratory parameters significant improvement in haemoglobin level and TSP Level in group A. Conclusion: - the trial drug "Santarpan Manth" is effective in promoting the growth and weight gain in children those suffering with PEM( Balshosha).
\end{abstract}

Keywords: Balshosha, PEM, Santarpan Manth, Weight, Growth.

\section{Introduction:-}

The World Health Organization (WHO) defines malnutrition as "the cellular imbalance between the supply of nutrients and energy and the body's demand for them to ensure growth, maintenance, and specific functions."

Malnutrition in India has been called 'The Silent Emergency or Silent Killer'. The proportion of undernutrition among children in India is one of the highest in the world. The malnutrition develops due to improper and imbalanced nutritional diet to their child because of low economic status of families. The essential ingredient of the diet i.e. Carbohydrate, Proteins, Fats, Vitamins, and Minerals must be component of a child diet. The presence of proper ratio of these substances in the body is called "well nutrition."'(1)

\section{Prevalence of Malnutrition:-}

The incidence of Protein Energy Malnutrition (PEM) in India in pre-school children is 1-2\%. PEM accounts for $5 \%$ deaths among pre-school children. The problem exist in all states. The PEM is not

\section{*Corresponding Author:}

\section{Astha Sharma}

PG scholar Department of Swasthavritta,

National Institute of Ayurveda,

Jaipur.

E-mail ID: ayurastha6989@gmail.com only a health problem but also a social and economical problem. (2)

The prevalence of malnutrition in India is $43 \%$, children under 5- year age are underweight and 48 $\%$ (i.e. 61 million children) are stunted due to chronic under-nutrition. India accounts for more than 3 out of every 10 stunted children in the world. In India $20 \%$ of children under age of five years suffer from wasting due to acute under-nutrition. More than one third of the world's children who are wasted live in India. It is the underlying cause for about $50 \%$ of the 2.1 million Under-5 year deaths in India each year. (3)

The NFHS-3 in 2006 found that $20 \%$ of children under- 3 years of age in Rajasthan were wasted, $34 \%$ were stunted and $44 \%$ were underweight. $20.4 \%$ of the children under-5 years suffered from wasting and $7.3 \%$ suffered from acute severe malnutrition.

PEM is a condition in which nutrient demands are not fulfilled due to any reason. So it is a deficiency disease and it could be managed by Santarpan. Principle of Santarpan Chikitsa is based on two factors, correction of Agni (digestive power) and nourishment of Dhatu. Thus, the treatment of malnutrition which is a result of Dhatu kshaya, emphasize on correction of agni, correction of srotorodha, dosha-dhatu-mala kshaya vriddhi and nourishment of malnourished tissues as holistic approach. The Trial drug composed of Gehun (sattu) and Tila tail having properties like Balya (provide strength) and Brimhana helps in the production of Prashasta Dhatus. Ghrita having 
properties like Deepana (Appetizer) acts as agnivardhan and drug like Pippali works as srotoshodhaka.

\section{Drug review:}

Santarpan Manth Yoga is selected from Charak Samhita. Santarpan Manth is a preparation containing the drugs i.e. Gehun (sattu), Ghrit, Pippali, Madhu, Sharkara and Tila tail having Deepana, Pachana, Srotosodhana, Vatakaphashamaka, Balya, Brimhana and Rasayana properties are very much essential in a malnourished predominant disease.

Gehun (sattu) and pippali having properties like anti-inflammatory, antihistaminic and anti- biotic, might be working against the local inflammatory process of the airways and preventing from further infections.(5)

Pippali and Ghrit works as Deepana drugs which properly potentiates the Agni thereby facilitating Aaharapaka as well as Dhatupaka at Jatharagni and Dhatwagni levels. As Pippali and Ghrit are having Rasayana properties they enhances the metabolic processes and circulation of nutrition(rasa).(6)

\section{Aims and Objectives}

The present research trial has been undertaken with the following objective.

To evaluate the role of Santarpan Manth in Protein Energy Malnutrition (PEM).

\section{Material \& Methods \\ Plan of Study}

Patients were selected with irrespective of age, sex, religion, caste etc. and randomly distributed into following 2 therapeutics groups with 15 patients in each group.

\section{Distribution of Patients}

\begin{tabular}{|c|c|c|c|}
\hline $\begin{array}{c}\text { Group / } \\
\text { Detail of } \\
\text { Group }\end{array}$ & $\begin{array}{c}\text { No. of Pt. } \\
\text { Registered }\end{array}$ & $\begin{array}{c}\text { No. of Pt. } \\
\text { completed } \\
\text { therapy }\end{array}$ & $\begin{array}{c}\text { Duration } \\
\text { of } \\
\text { therapy }\end{array}$ \\
\hline $\begin{array}{c}\text { A - Santarpan } \\
\text { Manth -1 }\end{array}$ & 18 & 15 & 3 month \\
\hline $\begin{array}{c}\text { B - Santarpan } \\
\text { Manth-2 }\end{array}$ & 17 & 15 & 3 month \\
\hline Total & 35 & 30 & $\begin{array}{c}3 \text { month } \\
\text { each } \\
\text { group }\end{array}$ \\
\hline
\end{tabular}

Out of 35 patients, 30 have completed the course and 30 patients were selected for making equilibrium in clinical and statistically analysis so that each group contains 15 patients.

\section{(1) Group A - Santarpana Manth-1}

In this group Santarpan Manth-1 was administered two times in a day.

The above trial drug was composed by following ingredients-
- Gehun (Sattu)
- Ghrit
- Til Tail
- Sharkara
- Pippali
- Madhu

Method and Dose- The patient had given aushadh dravya i.e. (Sharkara, Ghrit, Pippali, Til tail, and madhu ) $200 \mathrm{mg} / \mathrm{kg}$ body wt. per dose with double amount of i.e. $400 \mathrm{mg} / \mathrm{kg}$ body wt. per dose of gehun (sattu) . (7) For mixing, parents advised to take 4 times of water (acc. to manth kalpana) of Aushadh dravya.

\section{(2) Group B-Santarpana Manth-2}

In this group Santarpan Manth-2 was administered two times a day.

The above trial drug was composed by following ingredients-

\section{Gehun (Sattu) \\ Sharkara}

Method and Dose- The patient had given aushadh dravya i.e.(Sharkara) $200 \mathrm{mg} / \mathrm{kg}$ body wt. per dose with double amount of i.e. $400 \mathrm{mg} / \mathrm{kg}$ body wt. per dose of gehun (sattu) .For mixing, parents advised to take 4 times of water (acc. to manth kalpana) of Aushadh dravya

Follow up: Patient were advised to visit for follow up after every fortnight for the duration of 3 months.

\section{Duration of the total trial: 3 months}

\section{Material and methods}

- Selection of cases: - Total 30 cases divided in to two groups equally.

- Source:- Children for the present study were screened out from the O.P.D. and I.P.D. of P.G Department of Balroga, National Institute of Ayurveda, Jaipur.

- Age Group:- Children between 2 to 5 years were selected.

- Study design- An open randomised prospective clinical trial.

\section{Inclusive criteria-}

1. Age -2 to 5 years

2. Cases of grade I and II malnutrition (Acc. To Indian Academy of Pediatric) as given below.

\section{Anthropometrical Classification}

PEM is generally classified according to weight for age. Chronic malnutrition is classified according to height for age and acute malnutrition is classified according to weight for height. Classification according to weight for age is the most commonly used parameter to classify nutritional status. (8)

$$
\text { Current weight of the child } \times 100
$$$$
\text { (in } \mathrm{kg} \text { ) }
$$

Weight for $=$

Expected weight of the child for that age (i.e. Reference weight)

\footnotetext{
1. Indian Academy of pediatrics classification -

Normal- 100-80\%

Mild - Grade 1-79-70\%
} 
Moderate -Grade 2- 69-60\%

Severe - Grade 3- 59-50\%

Very Severe- Grade 4- $<50 \%$

\section{F .Exclusive Criteria-}

Any known systemic Disorders.

Known Congenital Anomalies.

Known Endocrinal /metabolic disorders.

G. Criteria for discontinuation of trial.

If the Complications arise between the trial period.

Parent not willing to continue
Assessment Criteria

Anthropometric Assessment:

- Weight

- Height

- Chest circumference

- Mid arm circumference

- Thickness of skin fold (Triceps or Infra scapular region)

Lab Investigations-

- $\mathrm{Hb} \%$

- Total Serum Protein.

\section{Observation and Results:}

Grade of Malnutrition after treatment in group A (Santarpan Manth-1)

Table No.1. Showing grades of malnutrition before and after treatment in group A

\begin{tabular}{|c|c|c|c|c|c|}
\hline \multirow{2}{*}{ S.N. } & \multirow{2}{*}{ Grades } & \multicolumn{2}{|c|}{ Before Treatment } & \multicolumn{2}{|c|}{ After treatment } \\
\cline { 3 - 6 } & & $\mathbf{N}$ & $\mathbf{N}$ & \multicolumn{2}{c|}{$\%$} \\
\hline 1 & Normal & 0 & $0 \%$ & 3 & $20 \%$ \\
\hline 2 & I(Mild) & 12 & $80 \%$ & 2 & $13.33 \%$ \\
\hline 3 & II(Moderate) & 3 & $20 \%$ & $\mathbf{1 5}$ & $\mathbf{1 0 0}$ \\
\hline
\end{tabular}

The observations shows that after treatment in group A $66.66 \%$ Patients were achieved normal weight for age, and rest $20 \%, 13.33 \% \%$ patients were in grade I, \& II respectively.

Grade of Malnutrition after treatment in group B (Santarpan Manth-2)

Table No. 2. Showing grades of malnutrition after treatment in group B

\begin{tabular}{|c|c|c|c|c|c|}
\hline \multirow[t]{2}{*}{ S.N. } & \multirow[t]{2}{*}{ Grades } & \multicolumn{2}{|c|}{ Before Treatment } & \multicolumn{2}{|c|}{ After treatment } \\
\hline & & No & $\%$ & No & $\%$ \\
\hline 1 & Normal & 0 & $0 \%$ & 3 & $20 \%$ \\
\hline 2 & $\overline{\text { I(Mild ) }}$ & 10 & $66.66 \%$ & 8 & $53.33 \%$ \\
\hline 3 & II(Moderate) & 05 & $33.33 \%$ & 4 & $26.66 \%$ \\
\hline & & 15 & 100 & 15 & 100 \\
\hline
\end{tabular}

Table no 2. Showed the grade of PEM after treatment in group B only $20 \%$ patients were achieved normal weight for age and rest $53.33 \%$ and $26.66 \%$ patients were in grade I, \& II respectively.

Statistical analysis of all features in group A ( Santarpan Manth -1)

Table No. 3. Showing statistical analysis of all subjective and objective feature in Balshosha.

\begin{tabular}{|c|c|c|c|c|c|c|c|c|}
\hline Features & BT & AT & \% & S.D. & S.E. & t value & p value & $\begin{array}{c}\text { Inter- } \\
\text { pretation }\end{array}$ \\
\hline Weight & 11.33. & 11.60 & 2.38 & 024 & 0.06 & 4.24 & $<0.0001$ & $\begin{array}{c}\text { Extremely } \\
\text { Significant }\end{array}$ \\
\hline Height & 97.36 & 97.44 & 0.07 & 0.22 & 0.05 & 1.49 & $<0.1$ & $\begin{array}{c}\text { Not } \\
\text { Significant }\end{array}$ \\
\hline Chest circumference & 56.92 & 56.95 & 0.05 & 0.17 & 0.04 & 0.14 & $<0.1$ & $\begin{array}{c}\text { Not } \\
\text { Significant }\end{array}$ \\
\hline Skin fold thickness & 8.66 & 8.72 & 0.69 & 0.09 & 0.02 & 2.55 & $<0.01$ & Significant \\
\hline $\begin{array}{c}\text { Mid arm } \\
\text { circumference }\end{array}$ & 14.35 & 14.48 & 0.41 & 0.10 & 0.02 & 2.46 & $<0.01$ & Significant \\
\hline Haemoglobin & 9.70 & 9.74 & 0.41 & 0.06 & 0.01 & 2.44 & $<0.01$ & Significant \\
\hline Total Serum Protein & 6.25 & 6.33 & 1.28 & 0.07 & 0.02 & 4 & $<0.001$ & $\begin{array}{c}\text { Highly } \\
\text { Significant }\end{array}$ \\
\hline
\end{tabular}


Table No.3. showing statistical analysis of all target features in group A shows that significant results were observed in skin fold thickness, mid arm circumference, and haemoglobin with ' $p$ ' value $<0.01$ in group A ; extremely significant result in weight with $\mathrm{p}$ value $<0.0001$; and highly significant result in total serum protein with $\mathrm{p}$ value $<0.001$ in group A.

Statistical Analysis of all features in Group B (Santarpan Manth -2)

Table No.4 Showing Statistical Analysis of all features in Group B

\begin{tabular}{|c|c|c|c|c|c|c|c|c|}
\hline Features & BT & AT & \% & S.D. & S.E. & t value & p value & Interpretation \\
\hline Weight & 11.57 & 11.63 & 0.51 & 0.10 & 0.02 & 2.41 & $<0.01$ & Significant \\
\hline Height & 94.43 & 94.46 & 0.02 & 0.05 & 0.01 & 1.74 & $<0.1$ & Not Significant \\
\hline $\begin{array}{c}\text { Mid arm } \\
\text { circumference }\end{array}$ & 14.10 & 14.12 & 0.14 & 0.07 & 0.01 & 1.46 & $<0.1$ & Not Significant \\
\hline Haemoglobin & 10.15 & 10.12 & 0.25 & 0.12 & 0.03 & 0.80 & $<0.1$ & Not Significant \\
\hline Chest circumference & 58.19 & 58.22 & 0.03 & 0.05 & 0.01 & 1.74 & $<0.1$ & Not Significant \\
\hline Total Serum Protein & 6.14 & 6.16 & 0.32 & 0.12 & 0.03 & 0.64 & $<0.1$ & Not Significant \\
\hline Skin fold thickness & 8.63 & 8.64 & 0.06 & 0.10 & 0.02 & 0.25 & $<0.1$ & Not Significant \\
\hline
\end{tabular}

Table No.4 Showing statistical evaluation of all target features in group B shows that insignificant results were noticed in height, mid arm circumference, Haemoglobin ,skin fold thickness and total serum protein with 'p' value $<0.1$. Significant result was noticed in weight with $p$ value $<0.01$.

\section{Discussion on results}

Discussion on anthropometry parameter:

The significant increase in weight, mid arm circumference, skin fold thickness in group A patients , may be due to the Srotorodha action of pippali and Agni is augmented due to Ghrit, resulting in faster weight gain due to better digestion, absorption and assimilation of diet taken. The drug also contain gehun (sattu) having Balya, and Brimhan properties: Ghrit having Rasayana properties resulting in formation of Prashsta Dhatu.

\section{Discussion on laboratory parameter: \\ Haemoglobin level:}

The significant increase in haemoglobin is due to Deepan and Brimhana effect of drug which harmonizes the function of Jatharagni as well as dhatwagni; thus promoting the formation of healthy Dhatus including Rakta. Pippali, one of the constituent of the drug compound is known to enhance absorption and bioavailability of various micronutrients needed for healthy erythropoesis.

\section{Total serum protein}

Total serum protein is a good indicator of protein energy malnutrition and is usually low in malnourished children. Total serum proteins are taken as an indicator of Rasa Dhatu and their increase denotes the formation of healthy rasa dhatus. This action may be due to Brimhana, Balya properties of Gehun, Sharkara, madhu and Ghrit.

\section{Probable action of the drug-}

Manth kalpana has been indicated for Santarpan. This therapy basically designed to fulfill the essential nutrients in the body. PEM is a condition in which protein and calorie requirement are not fulfilled by daily diet. So, there is need of extra protein and energy to correct this morbid condition. The main ingredient of Santarpan Manth is Gehun (Sattu). Wheat is rich in protein, carbohydrates and vitamin B complex. On the other hand, its Manth Kalpana is basically Brimhana in nature. So, it is very suitable for PEM. Sugar and Ghee are naturally Brimhana dravya and are indicated in daily routine to fulfill the energy requirement.

\section{Conclusion}

Protein Energy Malnutrition is a major problem globally. The problem is mainly related with routine intake of nutritional supplements through food. Ayurveda suggest Principle of Santarpan Chikitsa which is essential for proper growth and development of children suffering from Protein energy malnutrition. In the present study, laboratory parameter like total serum proteins, haemoglobin and anthropometric index of malnutrition are significantly increased by "Santarpan Manth 1 " whereas not significantly increased in haemoglobin, total serum protein and anthropometric index by Santarpan Manth -2. The constitents of Santarpan Manth-1 having properties deepana (appetizer), Balya, srotoshodhan, Rasayana might have caused positive result. So, It can be concluded that Santarpan Manth 1 is beneficial, safe and effective in management of Protein Energy Malnutrition.

\section{References:}

1. National Family Health Survey (NFHS 3), 2005 06, India: Volume I, \& National Fact Sheet, 
International Institute for Population Sciences, Mumbai, September 2007.

2. Park K. Park's Textbook of Preventive And Social Medicine , 24 ed, Jabalpur, MP; Banarsidas Bhanot; 2017, 676p.

3. Achar S T. Achar's Text book of Pediatrics, 3ed. Chennai, India.J. Vishwanathan; 1995. 69p.

4. Sharma PV. Dravyaguna- vijnana Vol-2. 3ed, Varanasi; chaukhambha bharati academy, reprint2013, 816p
5. Database on medicinal plants used in Ayurveda, vol7, The central council of Research in Ayurveda and Siddha, New Delhi, 2005, pg no.72

6. Agnivesh. Charak Samhita Dr.Gorakhnath Chaturvedi Hindi Commentary, reprint 2008, Varanasi; Chaukhambha Bharati academy, 440p

7. Suryakantha AH.Community Medicine with recent advances. 3ed, New Delhi; Jaypee Brothers Medical Publishers, $187 \mathrm{p}$. 